slightly higher titre, probably reflecting the usual laboratory errors. Of these negative sera, however, more than half had considerable titres $(1 / 64)$ with horse red blood cells. In one case the sheep agglutinin titre was less than $1 / 4$ and the horse agglutinin titre was $1 / 512$. This is in accordance with the findings of Lee et al. (1968). We think that every case that clinically resembles infectious mononucleosis should be tested with horse erythrocytes and differential absorptions if the classical Paul-Bunnell-Davidsohn test is negative.

Our results indicate that testing for E.B. virus-specific IgM antibodies is of great value for the aetiological diagnosis in diseases resembling infectious mononucleosis but without a positive heterophil antibody test result. One of the great advantages of this IgM test is that diagnosis as a rule can be made from a single sample. Viruses other than E.B. virus and cytomegalo-virus seem unlikely to be causal agents in diseases similar to infectious mononucleosis without heterophil antibodies, provided that the diagnosis is based on well defined clinical and haematological criteria.

We thank Professor P. Halonen, head of the department of virology, University of Turku, Professor O. Wager, head of the Municipal Bacteriological Laboratory, and Professor P. Forssell, head of the department of paediatrics, Aurora Hospital, Helsinki, for their help. The technical help of Mrs. L. Nurmi and Mrs. L. Heikinheimo is acknowledged. The investigation was supported by grants from the Sigrid Jusélius Foundation and the Finnish Medical Foundation.
Requests for reprints should be sent to Professor E. Klemola, Aurora Hospital, 00250 Helsinki 25, Finland.

\section{References}

Banatvala, J. E., and Grylls, S. G. (1969). British Medical fournal, 3, 444. Banatvala, J. E., Best, J. M., and Waller, D. K. (1972). Lancet, 1, 1205. Davidsohn, I., and Lee, C. L. (1964). American fournal of Clinical Pathology, 41,115 .

Evans, A. S. (1960). American fournal of Hygiene, 71, 342.

Evans, A. S., Niederman, J. C., and McCollum, R. W. (1968). New England fournal of Medicine, 279, 1121.

Evans, A. S. (1972). New England fournal of Medicine, 286, 836

Fraser, K. B., Shirodaria, P. V., and Stanford, C. F. (1971). British Medical fournal, 3, 707 .

Hampar, B., et al. (1971). Proceedings of the National Academy of Sciences of the United States of America, 68, 1407.

Henle, G., and Henle, W. (1966). Fournal of Bacteriology, 91, 1248.

Henle, W., and Henle, G. (1973). New England fournal of Medicine, 288, 263.

Hopsu-Havu, V. K., and Nikoskelainen, J. (1972). Acta Dermatovenereologia, $52,346$.

Klemola, E., and Kääriäinen, L. (1965). British Medical fournal, 2, 1099.

Klemola, E., et al. (1970). Fournal of Infectious Diseases, 121, 608.

Klemola, E. (1973). Annals of Internal Medicine, 79, 267.

Lee, C. L., Zandrew, F., and Davidsohn, I. (1968). Fournal of Clinical Pathology, 21, 631

Pathology, 21, 631. (1968). Fournal of the American Medical Association,
Niederman, J. C., et al. 203, 205.

Nikoskelainen, J., and Hänninen, P. (1973). Scandinavian fournal of Clinical and Laboratory Investigation, 31 , Suppl. No. 130, p. 32 .

Nikoskelainen, J. (1973). Serological and Epidemiological Studies on EpsteinBarr Virus Infections, Academic Dissertation, Turku.

Nikoskelainen, J., Hannuksela, M., and Palva, T. (1974). Scandinavian Fournal of Infectious Diseases. In press.

Schmitz, H., and Scherer, M. (1972). Archiv für die gesamte Virusforschung, 37, 332 .

Shirodaria, P. V., Fraser, K. B., and Stanford, F. (1973). Annals of Rheumatic Diseases, 32, 53.

\title{
Anaesthesia during Raised Creatine Phosphokinase Activity
}

\author{
G. OWEN, R. J. KERRY
}

British Medical fournal, 1974, 4, 75-76

\section{Summary}

No adverse effects were observed in a series of patients in whom he levels of creatine phosphokinase (C.P.K.) were known to be raised and who received anaesthetics. The need to exercise caution in the interpretation of screening test results for C.P.K. activity before anaesthesia is stressed.

\section{Introduction}

The association of malignant hyperpyrexia during anaesthesia and increased creatine phosphokinase (C.P.K.) activity has been reported (Ellis et al., 1972; Isaacs and Barlow, 1970). Most of the patients described with this condition have received suxamethonium together with a volatile anaesthetic such as halothane. Great increases have also been noted in the level of serum aspartate aminotransferase and serum alanine aminotransferase during the course of hyperpyrexia in these cases. Studies to establish a familial basis for this disorder (Isaacs and Barlow, 1970) have left some doubt as to the aetiology of the condition. It has been shown (Gosling et al., 1972; Meltzer et al., 1969) that raised levels of C.P.K. may

Royal Infirmary, Sheffield S6 3DA

G. OWEN, M.B., F.R.C.PATH., Consultant Chemical Pathologist R. J. KERRY, M.R.C.S., L.R.C.P., F.R.C.PSYCH., Consultant Psychiatrist

occur during the early stages of psychotic illnesses. There is some evidence to suggest that there might be some underlying myopathy in patients with raised C.P.K. (Meltzer and Moline, 1970; Denborough et al., 1970). The role of hyperpyrexia and the resultant change in cell permeability makes interpretation of enzyme studies difficult. Screening for raised C.P.K. levels before operation has been discussed by Ellis et al. (1972). The number of cases in which an anaesthetic has been administered to patients known to have raised C.P.K. activity is very small. We report here a group of patients who received anaesthetics without untoward effect on several occasions when their C.P.K. levels were known to be grossly raised. They were suffering from affective disorders. Daily C.P.K. measurements were carried out as part of their psychiatric investigation. Their uneventful course under anaesthetics suggests that raised C.P.K. activity is not always associated with anaesthetic complications.

\section{Patients and Methods}

Ten female patients were anaesthetized at times when they had raised C.P.K. activity (no male patients were included as the C.P.K. data was available only on female patients). They were all receiving electric convulsion therapy for affective disorders. Altogether anaesthetics were given to patients with raised serum C.P.K. activity on 28 occasions. The C.P.K. levels were between 200 and $400 \mathrm{mU} / \mathrm{ml}$.

The same drugs and techniques were used for all anaesthetics. The premedication was $0.6 \mathrm{mg}$ of atropine sulphate given intramuscularly one hour before the anaesthetic. 
The induction agents were $60 \mathrm{mg}$ of sodium methohexitone followed by $50 \mathrm{mg}$ of suxethonium bromide cation, and oxygen was given by mouth before and after each treatment.

\section{C.P.K. MEASUREMENT}

C.P.K. was measured using an L.K.B. enzyme analyser with reagents supplied by Boehringer. The normal ranges were established on a group of 72 healthy volunteers and found to be $10-60 \mathrm{mU} / \mathrm{ml}$ for women and $10-105 \mathrm{mU} / \mathrm{ml}$ for men. The C.P.K. activity at $35^{\circ} \mathrm{C}$ was estimated by linking the C.P.K. catalysed reaction through hexokinase to a reaction involving glucose-6-phosphate dehydrogenase and the conversion of nicotinamide adenine dinucleotide phosphate to its reduced form. Glutathione was included within the reaction mixture to "activate" the C.P.K. The increase in optical density at $340 \mathrm{~nm}$ due to the formation of the reduced nicotinamide adenine dinucleotide phosphate was plotted by using an LKB 8600 reaction rate analyser and is directly proportional to the C.P.K. activity. The reagents used were supplied by Boehringer in the form of a test kit for C.P.K. determination (Cat. No. 15926. TCAF). Solutions were prepared by Boehringer and the reaction was started by the automatic addition by the L.K.B. 8600 of $75 \mu$ l of creatine phosphate-solution 3 of the assay system. For all the solutions only half the recommended test quantities were used because the L.K.B. 8600 requires a minimum total volume of only 1 $\mathrm{ml}$ in each test cuvette.

\section{Results}

The results show that these patients had a combined total of 28 anaesthetics on occasions when their C.P.K. was grossly raised. Three patients each received six anaesthetics, three each had two anaesthetics, and four each had one anaesthetic during periods of raised C.P.K. In none of these patients were there any untoward effects despite levels of C.P.K. between 200 and $400 \mathrm{mU} / \mathrm{ml}$.

\section{Discussion}

This group of patients with raised C.P.K. activity had anaesthetics on a total of 28 occasions for electric convulsion therapy. None of the patients developed any untoward effects such as masseter spasm, haemoglobinuria, or any associated hyperpyrexia. If these patients had been in a general hospital and screening tests, including that for C.P.K., had been performed before the administration of general anaesthesia these anaesthetics might have been withheld from this group of patients. Since no adverse effect occurred in these patients this casts doubt on the value of C.P.K. measurement as a screening test in relation to malignant hyperpyrexia.

We thank Dr. H. A. Maher, formerly clinical assistant anaesthetist at Middlewood Hospital, Sheffield, who gave many of the anaesthetics.

\section{References}

Denborough, M. A., et al. (1970). Lancet, 1, 1138.

Ellis, F. R., et al. (1972). British Medical fournal, 3, 559.

Gosling, R., et al. (1972). British fournal of Psychiatry, 121, 351.

Isaacs, H., and Barlow, M. B. (1970). British fournal of Anaesthesia, 42, 1077.

Meltzer, H. Y., Elkun, L., and Moline, R. A. (1969). Archives of General Psychiatry, 21,731.

Meltzer, H. Y., and Moline, R. A. (1970). Archives of General Psychiatry, 23, 481 .

\title{
Ice Storage versus Perfusion for Preservation of Kidneys before Transplantation
}

\author{
D. F. SCOTT, D. WHITESIDE, J. REDHEAD, R. C. ATKINS
}

British Medical fournal, 1974, 4, 76-77

\section{Summary}

The results of simple ice stocage and prolonged perfusion storage of kidneys were compared in two series, each of 100 cadaver kidney transplants. There was a similar warm ischaemia time for both groups, but the average total storage time was 17 hours for the perfused kidneys as compared to three and a half hours for those stored in ice. The results of transplantation (as shown by transplant function at three and 12 months) were the same for both groups. There was no evidence of damage due to prolonged perfusion. The extra time, however, enabled a more conveniênt operation time to be chosen and more extensive tissue matching to be undertaken.

Prince Henry's Hospital, Melbourne, Australia D. F. SCOTT, M.D., F.R.A.C.S., Transplant Surgeon J. REDHEAD, M.B., B.s., Surgical Registrar D. WHITESIDE, s.R.N., Sister-in-Charge of Renal Unit R. C. ATKINS, M.B., M.R.A.C.P., Renal Physician

\section{Introduction}

Perfusion preservation of cadaver kidneys for periods of 24 hours has changed cadaver kidney transplantation from a disruptive emergency to a semi-elective surgical procedure. There have been doubts, however, about the effects of perfusion preservation on both early post-transplant function and subsequent rejection (Clark et al., 1973).

This paper compares the transplantation results of 100 consecutive kidneys stored by cooling in ice saline slush and 100 stored by hypothermic plasma perfusion.

\section{Patients and Methods}

All patients in the series were treated in the four Melbourne transplant units. Cadaver donor treatment, recipient selection, and management were essentially similar in each of the four units and did not change substantially during the five years of the study.

During the period April 1969 to January 1972100 consecutive cadaver kidneys were stored by cooling in ice saline slush and from February 1972 to December 1973100 cadaver kidneys were stored by hypothermic plasma perfusion and then transplanted. 